i tekhnolohichnoyi osvity, 7(1), 167-170. Retrieved from http://nbuv.gov.ua/ UJRN/nz_pmfm_2015_7\%281\%29_49. (in Ukrainian).

Yurzhenko, V. V. (2017). Shche raz pro proektnyy, kompleksnyy, fenomenolohichnyy metod [Once again about the design, complex, phenomenological method]. Trudova pidhotovka $v$ ridniy shkoli, 2, 12-18. (in Ukrainian).

DOI https://doi.org/10.32405/978-966-97763-9-6-2020-217-220

\title{
THE ROLE OF LEISURE CENTERS IN THE NON-FORMAL EDUCATION OF PUPILS OF SECONDARY LEVEL OF EDUCATION IN THE KINGDOM OF SWEDEN
}

Inna Kolodko, postgraduate student Institute of Education Problems of the NAES of Ukraine Kyiv, Ukraine

- he aim of the study is to reveal the role of leisure centers in nonformal education of pupils of secondary level of education in the Kingdom of Sweden.

Non-formal education of children is in the center of attention of the world community. The world community connects various opportunities with nonformal education: development of skills, improvement of physical condition, aesthetic education, etc. Leading international organizations, such as UNICEF and the OECD, express the positive impact of non-formal education on formal education, children's social activity, the development of children's social and emotional qualities, overcoming inequality, bullying, and others.

The Kingdom of Sweden represents the non-formal education system in the world best of all, as it is aimed at meeting social, professional and personal needs. In the Kingdom of Sweden, non-formal education is organized for all ages. Most non-formal education institutions are funded by the Government of the Kingdom of Sweden.

In the non-formal education of the Kingdom of Sweden, out-of-school education for children is singled out, which includes pre-school education and childcare after school or during holidays. Care for children after school or during the holidays is organized by leisure centers and outdoor leisure centers for children under 12 years. 
Leisure centers are part of the non-formal education of the Kingdom of Sweden and are governed by the Swedish Training Act. As stated in the Education Act, a leisure center is an educational part-time group activity for children when they are not at school or on vacation. The leisure center may exist as an independent organization, but it mainly cooperates with the school (Swedish Association for Local Authorities and Regions (SALAR), 2005).

Most leisure centers are open all year round and the daytime hours and are adapted to the work or study of the parents, or to the needs of the children. Most leisure centers are open from 7 am to $6 \mathrm{pm}$.

The act stipulates that groups of children must be of a certain number and age. Programs should be constituted according to the needs of each child and staff must be qualified to meet the needs of each child and have good learning performance. Leisure centers must use a national program approved by parliament, the same for preschools and compulsory schools. The institute that provides care for school-age children is responsible for ensuring that the center's staff plans, implements and evaluates the center's activities.

According to the Education Act, leisure centers must offer high school students qualified recreation and activities which meet with the needs of the comprehensive development of the child. To achieve this, you need to have a safe, fun and stimulating environment and focus on play, creativity and physical activity. All activities should be organized according to the age, development, needs, interests and experience of students.

As a rule, school staff and leisure center work closely to give the pupil of secondary level of education the opportunity to expand his or her abilities and knowledge throughout the day. Leisure center complements the school two components: 1) coming from a temporary category, the centers should admit pupils of the secondary level of education during school hours and during holidays. Caring for students should be organized so that parents could combine parenthood with work and studies. 2) basing on the content, centers give pupils of secondary level of education experience and knowledge, which to some extent differ from those they receive at school.

Every child has his or her own point of view that should be taken into account during the organization of leisure in the leisure center. Expressing their thoughts, students are able to understand what democracy is. So, the staff of the community center supports and encourages secondary students to express their views while organizing activities in the leisure center. 
Another form of non-formal education of secondary students is family child care. This alternative form of care for students, which is justified only for a small number of groups of children. In the family childcare one teacher cares for children. Groups in such institutions are small and the students of different age categories, and the activities are usually organized in the house who cares for the children. Sometimes family nanny cooperate with other nannies in rural areas and organize group activities. Like leisure time centers, family child care takes place after school or during vacations. These services also operate year-round from 8 am to $6 \mathrm{PM}$. But this care is not popular among the population of the Kingdom of Sweden.

Similar to leisure center as a form of extra-curricular activities is open leisure center. The concept of "outdoor leisure center" appeared in the Law on Education in 1995 and approved as an alternative leisure center for children from 10 to 12 years. Open leisure centers do not offer the same care and oversight and leisure centers, or family services out-of-school activities, but the activities are more adapted to the needs of students of the secondary level of education. Open outlets can be arranged along with leisure centers or from organisations such as sports clubs. The only difference between the leisure centre and outdoor leisure centre that in the last the entry is optional.

It is worth noting that the government of the Kingdom of Sweden controls the National Board of health and welfare to formulate recommendations for programs of leisure centers. This program defines the basic principles of child development and poses the problem of comprehensive development and care for the pupils of secondary level of education is an integral part of the educational process. In leisure centers the pupils of the secondary level of education should be equipped with the General information of history, culture and society. Therefore, organizing classes, teachers use a variety of forms: reading and listening to stories, different kinds of games and exercises, various types of creative activities.

It should be noted that leisure centers play an important role in nonformal education of the pupils of secondary level of education. The experience of the Kingdom of Sweden in organizing the leisure centers should be borrowed as an innovative practice for Ukraine. Considering the fact that most modern parents are busy, the leisure centers, are a great option for pupils of secondary level of education to spent free time. Leisure centers provide pupils of secondary level of education with the needs of self-realization, improve 
the intellectual, spiritual, physical, emotional level of pupils of secondary level of education through their participation in various activities.

Key words: non-formal education, Kingdom of Sweden, leisure centers, open leisure centers, family care for children, pupils of secondary level of education.

\section{References}

Dregalo, A., Ulyanovskyi, V. (1996). Sotsialna robota u Shvetsii. [Social work in Sweden]. Arhangelsk. - p. 55-64.

Employment developments in childcare services for school-age children. Sweden. European Foundation for the Improvement of Livivng and Working Conditions. (1999). Retrieved from: www. Oecd.org/education/school/2534972pdf.

Skolverket (2010:800) Retrieved from: http://www.skolverket.se/

\section{ВИХОВНИЙ ПОТЕНЦІАЛ ДЕКОРАТИВНО- УЖИТКОВОГО МИСТЕЦТВА В ЗАКЛАДАХ ПОЗАШКІЛЬНОÏ ОСВІТИ}

\section{Анна Корнієнко, к. пед. н, с.н.с.}

Інститут проблем виховання НАПН України

м. Київ, Україна

етою статті $\epsilon$ аналіз виховного потенціалу декоративно-ужиткового мистецтва в закладах позашкільної освіти.

Удосконалення позашкільної освіти України нині здійснюється в контексті загальноєвропейських і світових гуманістичних освітніх парадигм. Ці зміни стосуються оновлення змісту навчально-дидактичних матеріалів, форм і методів навчання та виховання підростаючого покоління. У тому числі в гуртках і студіях декоративно-ужиткового мистецтва закладів позашкільної освіти.

Використання декоративно-ужиткового мистецтва як засобу етнокультурного виховання учнів актуальне тим, що декоративно-ужиткове мистецтво у виховному і освітньому процесі, дозволяє вирішувати проблему естетичного виховання. Саме в процесі таких занять у педагога $є$ можливість встановити з дитиною емоційний контакт, емоційне спілкування. 